\title{
Revisited: Muslim Women's agency and feminist anthropology of the Middle East
}

\author{
Sertaç Sehlikoglu ${ }^{1}$
}

Published online: 23 September 2017

(C) The Author(s) 2017. This article is an open access publication

\begin{abstract}
This article locates imaginative aspects of human subjectivity as a feminist issue by reviewing the concept of agency in the genealogy of Muslim and Middle Eastern women in anthropological and ethnographic literature. It suggests that, if feminist scholarship of the Middle East would continue approaching to Muslim women's agency -as it has been doing for decades-, it should do so as an epistemological question and thus expand the limits of ethnographic and analytical focus beyond the broader systems, such as family, nation, religion, and state. As an example to this proposition, the article then discusses the recent work on aspects of selfhood that escape from the structures, rules, systems, and discursive limits of life but captures imaginations, aspirations, desires, yearnings, and longings.
\end{abstract}

Keywords Agency · Muslim women · Anthropology of the Middle East · Desire · Feminist theory

\section{Women's Agency in Anthropology of the Middle East}

It would be reasonable to suggest that women's agency has been the primary focus in the anthropology of the Middle East since feminist anthropologists have entered into the area studies in late 1960s. Like much early feminist scholarship, the feminist anthropology of the Middle East also took a critical distance to the former scholarship and its "male bias" (Reiter 1975, Moore 1988). As I discuss in following pages more extensively, the particular type of

An abridged version of this review will be published in Turkish, In Cenk Özbay and Ayfer Bartu Candan (Ed.s) (2018) Kültür Denen Șey? Türkiye'den Antropolojik Yaklașımlar, İstanbul: Metis Yayınları.

Abdullah Mubarak Al-Sabah Research Fellow in Islamic and Middle Eastern Studies

Sertaç Sehlikoglu

ss935@cam.ac.uk

1 Pembroke College, University of Cambridge, Pembroke College, Trumpington Street, CB2 1,

Cambridge, RF, UK 
male bias in they had to engage with and somewhat write against was also loaded with colonial undertones. Writing about women with stereotypical and sensationalistic tones (Granqvist 1947; Hansen 1961; Reed 1957) was the norm.

In this context, the feminist Middle Eastern scholarship sought to avoid reductionist representations of women in the Muslim and non-Muslim Middle East from the beginning, mostly by investing into those women's agentive capacities. However, they have done so in different ways at different times; which is why I will discuss the feminist approaches to women's agency through four waves; arguing that each one of the four waves had different understandings of the content of "reductionism" with respect to women in the region but especially the Muslim women.

These four waves are:

1. First Wave: from the late 1960 s to the late 1970 s

2. Second Wave: the 1980s till the late 1990s

3. Third Wave: the 2000s till the 2010s

4. Fourth Wave: the 2010 s

Each one of these waves exerted conscious efforts against the reductionist approaches to women while developing both ontological and epistemological critique to such approaches. However, the way they developed their critique was often informed by the scholastic limits of the literature - that they engage with. I will be reflecting on those limits as I discuss each one of the waves. ${ }^{1}$

\section{The first wave: Founders writing against the male bias}

The first wave of the late 1960s and early 1970s had to deal with everything other feminist anthropologists had to deal with. These multiple problems can be summarised into two groups: 1) methodological limitations that marked the field as negligence to women, and 2) the male bias forged into early anthropological theory. The methodological limitations are basic boundaries that prevent male ethnographers from entering into female zones and women's spaces. The problem of access was especially relevant in societies (such as in the Middle East) where gender segregation arranged social interactions. However, once this practical problem of access started being lifted with women's entrance into the field (often as assistants or unrecognised wives of male ethnographers) in the 1950s, it became apparent that the negligence of women's circles or their role in larger society was beyond an issue of practicality. Apparently, anthropological negligence to women was about a more complex issue at stake, which was addressed during this first wave feminist anthropology.

The 'androgenic' (Kandiyoti 1996), or the 'male bias' as Henrietta Moore calls it in her now classic "Anthropology and Feminism", had established ethnographically poor work with androcentric perspectives at the foundation of early anthropology. The male bias had three layers: 1) The first layer was the bias of the anthropologist himself, who tended to

\footnotetext{
${ }^{1}$ Despite the rightful critiques to other uses of the term wave as reductionist by feminists, I mainly use the term to point out how different scholarly attitudes were initiated within certain periods through intellectual interactions and the ways in which developments 'cocooned' within the preceding formation.
} 
neglect the significance of women in any society, reflecting the biases he himself had. 2) The second layer was the bias cultivated in the society that is the subject of the research. 3) The third layer was the bias embedded in the Western culture that, in turn, tends to disregard the relatively more egalitarian relationships between sexes in certain non-Western contexts. Because of those Western biases (that are often observed at the level of analysis), "researchers are very often unable to understand this potential equality because they insist on interpreting difference and asymmetry as inequality and hierarchy" (Moore 1988: 2). ${ }^{2}$

Reverting the male bias was especially important for the first wave (late 1960s -1970s) feminist Middle Eastern scholarship for two reasons. Firstly, the segregation was shaping the public sphere in many parts of the Middle East which means women's sphere was not accessible to male researchers. Yet, male scholars were oblivious to the limited access they had and thus not necessarily treated this ethnographic limit as an obstacle to academic integrity or competency. A good example to this would be Richard Antoun's article published in American Anthropologist in 1968 where he focused solely on 'modesty' based not on a thorough ethnographic research, but on distant observations and on religious and sacred texts. This was quickly refuted by feminist scholarship (Abu Zahra 1970.) Nadia M. Abu-Zahra from Oxford University pointed out the misinterpretations of Antoun, presenting a good example to how male bias would mean poor data collection and normative analysis. The second reason as to why reverting the male bias was especially important to feminist Middle Eastern scholarship was that the male bias was nourishing sensationalist and eroticizing colonial gaze that feminist scholars found troubling at multiple levels. This aspect of the male bias (colonialist male bias) would be critiqued after 1980s.

The first wave in anthropology of the Middle East embodied the initial attempts and efforts to focus on women in the Muslim world with the goal of correcting the scholarship that mostly focused on men, reflecting the common tendencies of their time in emerging feminist studies (Aswad 1967, 1974, 1978; Fallers and Fallers 1976; Fernea and Bezirgan 1977; Keddie 1979; Keddie and Beck 1978; Maher 1974; Makhlouf 1979; Tapper 1978; Vreede-de Stuers 1968). This wave corresponded to the emergence of an "anthropology of women" that tackled "the problem of how women were represented in anthropology" (Moore 1988: 1). Its initial agenda, as Moore puts it, was to "correct male bias in reporting" and to build up "new data on women and women's activities" (ibid: 2).

In this first wave of literature, we begin to see the seeds of agency, which is linked to areas of resistance and therefore seen as a struggle for (self-)empowerment. In fact, the search for explicit resistance against male dominance in order to locate women's agency (Mahmood 2005) continues until the third wave, as the third wave also overlaps with the piety turn, which will be discussed the corresponding section.

The main theoretical framework used in this first wave was influenced by the Marxist feminist approach, due to which the first wave directed its initial interest toward the areas of power and status. Women's leisure activities, such as reception days, formal teas, and other religious and formal gatherings, for instance, were a major focus of interest during the 1970s (Aswad 1967, 1974, 1978; Benedict 1974), Iran (Good 1978), and Lebanon (Farsoun and Farsoun 1974). Such activities that were organised and attended by the elite women of the

\footnotetext{
${ }^{2}$ Moore (1988) suggests Rogers, 1975; Leacock, 1978; Dwyer, 1978; see chapter 2 (of the same work) for further discussion of this point.
} 
Middle East were seen as a venue of exchange and empowerment, and became a common focus of the early feminists.

The early work of the first wave also documented and touched on the major concepts, such as modernity (Makhlouf 1979), modesty (Abu Zahra 1970; Antoun 1968), and nationalism (Fernea and Bezirgan 1977). However, their relationship with those concepts was mostly descriptive and we would witness a thorough formulation of those concepts in later years/decades. Fernea and Bezirgan's edited volume, for instance, is a good representative to the work of this wave. The book locates women and their "experiences," as they put it, between two ends of a spectrum where what they call "the word of God" (Qur'an) is on the one end and "the word of men" (tribal and family custom) on the other. They continue by bringing out twenty-three women's stories from twelve countries and locate various experiences between these two ends. This approach has not been substantiated since then. Nevertheless, the concepts they have touched on would later be discussed in depth during the second wave and continue shaping discussions among researchers in Middle Eastern Studies today.

\section{The second wave}

The second wave emerged during the late 1980s and early 1990s and continued until the early 2000s. This period coincided with two major theoretical turns which immediately affected the second wave (and advanced further in the third wave). The first theoretical turn that coincided with the second wave was postcolonial critique, pioneered by Edward Said (1978) and Talal Asad (1973). In Ortner's terms, "it became impossible to look at the so-called Third World without understanding it as part of a history of colonial (and, for the Marxist, capitalist) expansion" (2016: 51) in anthropology (and, inevitably in anthropology of the Middle East). The second theoretical turn was of course the rise in gender and sexuality studies, enabled by Michel Foucault's History of Sexuality (1978) - original French "L'Histoire de la sexualité" (1976)- and later on by Judith Butler (1990a), resulting the feminist scholars to expand their feminist critique to the makings of gender as a normative system. It was during this time that feminist interdisciplinary schools started to transform from "Women's Studies" into "Gender Studies", reflecting the change in their scope of analysis.

The second wave marked the rapid growth of literature on Muslim women, with seminal works by major anthropologists and a wide array of focuses, ranging from family and gender in Egypt (Badran 1996; Early 1993; Hoodfar 1997; Watson 1992; Zuhur 1992), to elite life in Saudi Arabia (Altorki 1986), and from the zär cult of female healers in Sudan (Boddy 1989) to honour in Bedouin society (Abu-Lughod 1986), as well as multi-sited ethnographies on family and Islamic law (Mir-Hosseini 1993). The epistemological dynamism of the issues related to social and political makings of gender were discussed during this time was accompanied by theoretical depth and postcolonial touch to its feminist stand.

Concepts such as nation, religion, and state were formulated and discussed as foundations of the patriarchy - a term that was severely critiqued amongst feminists throughout 1980s and 1990s. Influential collected volumes elaborated on those concepts through comparative work. "Woman-Nation-State" edited by Floya Anthias and Nira Yuval-Davis (Yuval-Davis et al. 1989) and "Women, Islam, and the State" (Kandiyoti 1991) were two of the most prominent works that approached the three 
patriarchal mechanisms and how they objectify women by focusing on different parts of the Muslim Middle East. Conceptual formulations provided during the second wave then enabled the more grounded and advanced studies we witnessed during third wave, such as European Muslim womanhoods, or Egyptian pious masculinites. The second wave, then, provided the perfect cocoon for the development of feminist scholarship on women, gender, nation and religion, as larger themes to be explored, rather than documenting women's accounts in area studies - as marked by the first wave.

Signified by the vibrant scholarly environment and diverse body of interests around Muslim and Middle Eastern women, the second wave witnessed three interconnected accomplishments: 1) More systematic formulations of womanhood, gender, and Islam 2) theoretical advancement in feminist Middle Eastern scholarship as a form of non-Western feminism, and, 3) systematic critique of androgenic perspectives embedded in orientalist studies -I refer to those particular androgenic perspectives as colonialist male bias).

In Deeb and Winegar's observation, one of the heavily debated concepts, honour, was influenced from the theoretical advancement of the second wave. During this wave, honour was no longer treated "as a static cultural determinant, but rather as a dynamic discursive practice related to other structures of power" (Deeb and Winegar 2012: 542). This dynamic analysis is related to the second wave's ability to move beyond the issue of male dominance by, instead, "addressing patriarchal family formations, brother-sister relationships, family status law, and the relationship of kinship to the state" (ibid).

In this second wave of literature, we witness how the seeds of agency of Muslim women have started to sprout in the emergent discourses of subjecthood. Saba Mahmood refers to this work as "analysis of subaltern gendered agency" (Mahmood 2005: 7). One of the most influential scholars of this wave is Fatimah Mernissi, who argued that Arab culture views female sexuality as active and potent (Mernissi 1987). In her argument, Islam in turn attempted to control this active female sexuality by a series of regulations. Although many later found Mernissi's attack on Islamic patriarchy (and religious women's adaptation of such rules) a dismissal to women's choice, back then, it was considered as "a refreshing departure from Western depictions of female passivity in the orthodox Freudian vein" (Kandiyoti 1987).

Moreover, the second wave reflected the shift away from a solely geographical focus toward ontological grounds of understanding the subjecthood of women in the region and opened a path to the third wave, which centres on the Muslimhood of women both in the region and outside of the region, that is, Muslim female immigrants living in Europe. As a result, the second wave gradually opened up theoretical possibilities for discussing Islamic or Muslim feminism in following years (Sharzab 2001).

The second wave also registered the rapid growth of literature on women in the region and not only contributed to non-Western feminist theory (Abu Odeh 1993; Kandiyoti 1987, 1988; Moghadam 1994), but also contested and countered ethnocentrism and thus played a part in the evolution of postcolonial feminist theory. According to many scholars in this wave, colonial perspectives in studies of Muslim women were inherently male-oriented, and they criticised those earlier works for conveying this colonialist male bias into many other (including future) work on the Middle East (Afshar 1993; Harper 1985; Hoodfar 1992; Kabbani 1986; Moors 1991).

Consequently, the image of women in the harem was subjected to serious attacks (Ahmed 1982; Alloula 1986; Yeğenoğlu 1998). Influenced by two critiques of 
orientalist literature (Said 1978; Alloula 1986) in her book "Colonial Fantasies", Meyda Yeğenoğlu suggests that it is in the very foundation of the unconscious, where the (impotent) gendered orient is sexualised, fantasized, and eroticised as an object of desire (Yeğenoğlu 1998). In fact, the (male) colonial gaze depicted the Orient as a female, gendered, disempowered other. Yet, in their depiction of women of the Middle East, Yeğenoğlu argues, the veil was the essential subconscious component to maintain this imagination. "Yeğenoğlu says, "the answer is the question by which the European traveler or colonizer establishes the required imaginary anchor for himself to securely assert his subjectivity as sovereign" (1998: 49). The analysis of the subconscious proved prescient when the orientalist male bias was so easily and hastily reinvigorated in post 9/11 era, despite decades of progress made.

The troublesome portrayal of Muslim women "as victims of male brutality who must be rescued from traditional, oppressive male morality, which is imagined as a total control over female bodies and actions" (Ewing 2008: 1-2) has proven to be the dominant obstacle in Middle Eastern scholarship. Indeed, any attempt that immediately interprets women's -who are, among other things, Muslims- actions as forms of "liberation from the male gaze" or "male domination" embodies this historically loaded masculinist gaze. The problematic perception Ewing critiques still haunts studies on gender in Muslim contexts. It has resulted from two interconnected problems. The first problem relates to the imagining of Muslim women as the impotent objects of an aggressive, religious, and male-dominant cultural system, to which both the second and the third wave developed a response. The second problem is a failure to recognise the multiplicity of the subjectivation process in the daily lives of Muslim women, which is fully addressed today thanks to the emergence of the fourth wave of studies discussed below.

However, before moving on to discussing the third wave, I would like to point out one more problem that haunted the second wave - and was also addressed by the next generation of feminist scholars of the Middle East. This problem was the uneasy relationship secularist feminists had with female advocates of Islamic revivalism (of the 1990s).

\section{Women's political agency during Islamic revivalism}

An important twist to the second wave was the rising Islamic Revivalism in many parts of the Middle East. The Egyptian and Turkish cases were especially intriguing to many scholars in understanding Islamic Revivalism of 1990s. In Turkey, the Refah Party was gaining rise in the mid-1990s and women's branches were actively strengthening the party's politics at a grassroots level. The voluntary "submission" of women to what will eventually become (if not already is) a regime that is oppressive to women presented an uneasy dilemma to several (secularist) feminist scholars. On the one hand, the Islamic women in revivalist politics were more active than ever -thanks to secularism. While, on the other hand, they were also submissive for embracing certain seemingly oppressive principles of the religion, such as obedience to husband, uneven share in inheritance, various forms of the veil, and so forth. The tendency in the late 1990s was to discuss Islamic women's active participation in revivalist politics as a "paradox". This term was in fact a continuation of a feminist critique of women's politics. It allowed 
feminists not to assume feminist consciousness in every woman politician, and to further their demands for gender equality (Arat 1989).

However, the same paradoxical rhetoric was often applied to Islamic revivalism and women's role in it rather too swiftly, with work often built on a binary between liberalism and Islamism. The critique sometimes reflected secularist prejudices, recurrently failing to recognise any particular feminist agency in Islamic women's involvement in politics, by denying not only their agency but also the complex nature of their political formation and subjectification. They were, instead, seen to be caught in false consciousness and thus trapped in an Islamic paradox where they are empowered by secular values (ie. political and democratic rights) but demanding lack of them.

All of these problems would be fully addressed during the third wave.

\section{Third wave: Post 9/11}

By the time we reached the year 2000, the colonialist male bias was losing its popularity and an archaic sensationalist approach to Muslim women was almost against the new scholarly norm. However, with 9/11 (2001), colonialist perspectives quickly reemerged. Some scholars joined the Western mainstream media to suggest how Islam can become a basis for violence and is simultaneously the cultural opposite of Western cultures and values - democracy included (Boroumand and Boroumand 2002; B. Lewis 2004; Palmer and Palmer 2004). ${ }^{3}$ The refuted colonialist male bias resurrected with the new "Islam and terror" debate, with a gender twist. There has also been influential work on activism of secularist Muslim feminists (Al-Ali 2000), posing a potential challenge to the resurrection of male bias that was revisiting the former orientalist discourses of male domination and Islamic patriarchy. The resurrected male bias, combined with the uneasy relationship secularist feminists had with Islamic women's active participation in revivalist politics, provided the theoretical background (and demand) to revisit the issues related to Islam and women -and how to connect the two to the critique of patriarchal ideologies.

The third wave of scholarship on Muslim women was developed in the mid-00s. Scholars in this wave sought to investigate the "insider's voice" at both the ontological and empirical levels, which eventually deepened their ability to recognise agency. Inevitably, several scholars studied how to write against stereotypical images of Muslim women by developing a critical language and theoretical tools (Barlas 2002; Bullock 2002; Deeb 2006; Mahmood 2005; Peek 2005; Shively 2005).

The first and the third wave share a common concern about women's agency, yet the third wave theorized the concept of agency itself and did this by aiming at the roots of the way agency is theorised. Mahmood's work was the pioneer of this new stream of thought, as she recognised pious self-making and how devout Muslim women's feminist agency has been left unnoticed for several decades. Part of Mahmood's work, especially where she discusses the Islamic concept al-haya (shyness, modesty) as a virtue and thus something that requires continual agentive investment into a particular

\footnotetext{
${ }^{3}$ Many others were against this stream. The new postcolonial post 9/11 stream was often represented by Asad (2007), Hefner and his work on Islam and democracy (Hefner 2001; Hefner 2011), Mamdani (2002) and Esposito's attempts to disengage Islam from global terrorism in the mind of the public (Esposito 2002).
} 
type of ethical self-formation. Failure to identify such agency in earlier works, in Mahmood's assessment, was the result of a particular (liberal) formulation of agency, that could only recognise agency in the presence of resistance.

The theoretical perspective developed by Mahmood was the result of a combination of three paradigmatic turns. The first was a critique of anthropology as a secular knowledge-making mechanism by Asad (2003) and his pioneering work on approaching religion (Islam) anthropologically as a "discursive tradition". The second influence was the performative turn, as Vikki Bell (2008) calls it, in feminist theory that evolved after Judith Butler's series of works on gender and performance by the end of the '90s (Bell 2008; Butler 1990b, 1999). This turn further developed Simone De Beauvoir's proposition, "One is not born, but rather becomes, a woman," by theorising this gendered becoming beyond the limits of womanhood and applying it to all forms of gendered and sexed subjectivities. The third one was the agency turn in social theory that is, in the words of Webb Keane, "competing over whose approach better recognizes human agency and self-determination” (Keane 2003: 234). Mahmood's work was able to connect these three paradigmatic turns and develop a strong recognition of pious Muslim women's agency. It is in this scholarly context, Mahmood's interrogation of the "liberal subject" was appreciated in anthropology circles.

The term "discursive tradition" has allowed some scholars, including Mahmood, to delve into the contemplative, intersubjective, and introspective aspects of Islam and how these play out in the everyday lives of Muslims (Deeb 2006; Henkel 2007; Hirschkind 2006; Mahmood 2005). In her recent work on the Islamic ethics of giving, Amira Mittermaier (2014) says that approaching Islam as a discursive tradition is essential but still limited in understanding contemporary forms of religious subjectivities. Instead, she suggests thinking of Islam "dialogically", which she explains as "proceeding from neither Islam nor the "secular" as a given" (Mittermaier 2014: 280). I believe that the term is especially necessary in understanding Islamic realms of life, as in Mittermaier's example, Islamic charity and alms-giving. Although the term "discursive tradition" enabled an understanding and analysis of the temporal aspects of Islamic subjectivities, it also further obscured other, seemingly less Islamic (and even non-Islamic) realms of life. This problem is present especially in Mahmood's work (2005).

Mahmood's "Politics of Piety" (2005) is of crucial significance to this third wave, and to my discussion of women's subjectivity, desire, and agency in the Middle East. In her work on women in the Egyptian "piety movement", Mahmood examines and offers a critique of secular and liberal modes of agency by contrasting the latter with the conceptions of agency that underlie the practices of pious women in Cairo. Mahmood's ethnography enables her to explore why Muslim women would desire to submit to pious norms and obligations. In doing so, she is forced to rethink the assumption at the heart of secular-liberal thought (and feminism) that the desire for freedom is universal and crucial to an understanding of agency.

Mahmood explores human agency beyond the realms of resistance, power, or domination, seeing it rather "as [a] capacity for action that historically specific relations of subordination enable and create" (Mahmood 2005: 27). Therefore, in order to solve such a theoretical predicament in the context of Egypt, she proposes to "explore those modalities of agency whose meaning and effect are not captured within the logic of subversion and resignification of hegemonic norms" (ibid: 15). For example, 
Mahmood looks at the aforementioned Islamic concept al-haya, which is often used as an indicator of Islamic control over women's sexuality. Mahmood shows how religious Muslim women work to achieve a modest disposition by carefully aligning their exterior practices with interior emotions and intentions through the same concept. For the members of the mosque movement, a pious disposition is both a means and an end towards establishing an embodied piety. In doing so, Mahmood convincingly demonstrated that pious women's appropriation of religious concepts in fact contains a particular form of agency that had previously been neglected by feminist theory. Her ground-breaking work triggered a post-secular diversion in the ontology of feminist agency as it forced feminist theorists to question the limits of feminist thinking in realms of piety (Bracke 2008; Braidotti 2009) and contributed to post-colonial feminist theory.

Although Mahmood's ethnographic and theoretical scope is significant and consequential as a post 9/11 work in the anthropology of Islam and of the Middle East, it is too specific to be employed as a theoretical model applicable to all Muslim gendered agencies, according to Bautista (2008). He questions the limits of Mahmood's approach to agency and Muslim women, especially in contexts other than the women's mosque movement in Egypt. Another critique regarding the applicability of Mahmood's conceptualisation is raised by Bangstad (2011). Unlike Bautista, Bangstad questions whether Mahmood's ethnography sufficiently captures other gendered Muslim pieties and agencies in Egypt. He draws attention to the fact that the particularity of the mosque movement in Cairo and the background (class, age and ethnicity) of the participants of this movement are not explored in much depth in Mahmood's analysis. These factors are crucial to positioning members of the piety movement in a broader socio-political and economic context, accounting for the specificities of their experiences of piety as well as non-pious dimensions of their everyday lives.

From the beginning of 2000 onwards, under the influence of Mahmood's work, Muslim women's subjectivity began to be perceived as that of agents, but also as religious agents, whose agency does not necessarily correspond to liberal expectations. The third wave was on the rise at a time when anthropological as well as feminist theory strongly questioned human agency and its limits in post-structuralist theory and asked "[q]uestions not only of 'agency' (and 'resistance') but of pain or fear or confusion, as well as various modes of overcoming these subjective states" (Ortner 2005: 34). Thus, the third wave simultaneously achieved two parallel results. First, it developed a careful positioning on the question of gender where the former waves were concerned more with women's issues and gender relations. Second, it theorised and elaborated on feminist agency.

\section{The piety turn and Muslim Women's ethical self-making}

Crucial aspects of agency in the lives of Muslim women, such as liberation and choice, were theorised through their relation to God in the third wave in gender studies in the Middle East. Thus, this wave developed rich and insightful ethnographies to enlighten Muslim women's experiences as Muslims. Yet, this Muslimhood portrayed in the literature relapsed to secularist presuppositions, yielding a unilinear understanding of religion - and thus leading to a poor formulation of subjectivity. 
The third wave moved its focus away from gender relations to an enhanced connection to women's agency and piety. This enabled a reflection on women as followers of faith (Deeb 2006; Huq 2008; Mahmood 2005). Mahmood's work has been so influential that led to a number of work focusing on piety, creating its own term; that is called the piety turn (Bayat 2002; Deeb 2006; Hasan 2009; Heryanto 2011; Hitq 2003; Huq 2008; S. Huq and Rashid 2008; Jones 2010; Rozario 2011; B. F. Soares 2004; Tong and Turner 2008; Weintraub 2011; Widodo 2008).

This stream led to two major effects in the field of Middle East studies. First, the piety turn stressed and documented the multiple meanings and heterogeneity behind the believing, devout, and pious subjectivities of Muslims and stretched the limits of secular thinking (Braidotti 2008). Second, beyond Mahmood's work and the individual works focusing on piety after Mahmood, the impact of her work, and the ontological prevalence of piety in the literature that began after it, inevitably led pious forms of subjectivity to dominate other subjectivities in studies of believing (and practicing) Muslims.

\section{The fourth wave: Departure from piety to agentive joy, desire, and fun}

The fourth wave has emerged with a call to go beyond the charm of the piety turn and seeks to unravel subjectivities that are not immediately associated with ethical selfmaking. In a recent article, Deeb refers to this departure as a scholarly attempt to write against Mahmood (and Hirschkind), whose works "have been taken up more broadly such that "the pious Muslim" became the only visible Muslim" (Deeb 2015: 95 emphasis by Deeb). Although both the third and fourth waves incorporated a postcolonial tone combined with a critical distance from attempts at locating women's agency in the form of extremism in the post-9/11 era, the latter is marked by a departure from the piety turn.

As a visible indicator of this departure, scholars in the fourth wave have experimented with new theoretical and methodological perspectives to understand gendered Muslim subjects and their agency in relation to more diverse and complex realms of their lives. One of the most well-known attempts to move away from centralising the religiosity of Muslim women is the body of work that shifts the scholarly gaze to fashion as an attempt to bring out joys and pleasures of Muslim women (Al-Qasimi 2010; Altinay 2013; Balasescu 2007; Gökarıksel and Secor 2010; Kilıçbay and Binark 2002; Osella and Osella 2007; Sandikci and Ger 2007; Tarlo 2010; Tarlo and Moors 2007; Yaqin 2007). While some of this work attempted to find ways to connect pleasure and piety (Gökariksel and McLarney 2010; Jones 2007, 2010), others have used fashion industry of believing Muslims in Europe as a challenge to Islam vs. the West binary (Lewis 2013; Moors 2009; Tarlo 2010; E. Tarlo and Moors 2013). This body of work also used fashion to respond to sensationalist attitudes to visible Islam with a feminist critique.

Another set of work that has marked fourth wave that had interest in different aspects of everyday life in the way it goes beyond the "mosque", are those that focus on youth culture (Bayat 2002; Menoret 2014), art (Winegar 2006, 2008), leisure (Deeb and Harb 2013; Harb and Deeb 2013; Hazbun 2008; Khalili 2015), desire (Hasso 2010; 
Menin 2011; Ozyegin 2015), sports (Benn and Pfister 2010; Farooq 2010; Hoodfar 2015; Kay 2006; Sehlikoglu 2013, 2014a, 2014b, 2016) and ordinary everyday life (Bayat 2013; el-Aswad 2012; Schielke and Debevec 2012). Works from this wave that contributed to the question of agency and subjectivity were those that focused on everyday life, ordinariness, and desire, to which I will return shortly. The question of everyday life, in particular, has recently been a major topic of debate amongst the scholars of the Middle East and Islam, and thus deserves a particular attention in this essay.

One of the important theoretical contributions to this wave is Soares and Osella's edited volume on Islam and politics, as it questions the ways in which the third-wave literature has prioritised religious agency instead of exploring other aspects of Muslims' everyday lives (Soares and Osella 2009). Scholars within this wave attempted to confront a particular trend in sociology and anthropology that overemphasises religion when studying Muslim cultures and Muslimhood, which, in turn, others them. This theoretical concern not only expanded the definition of human agency in studies of women in the Middle East, but also questioned the validity of linking every act performed by Muslims to Islam as the core cultural component of their subjectivity. This tendency in the literature "to project Islam as a perfectionist ethical project of selfdiscipline, at the cost of the majority of Muslims who - like most of humankind - are sometimes but not always pious and who follow various moral aims and at times immoral ones" (Schielke 2010: 2), was then attempted to be rectified by a focus on everyday life of ordinary Muslims. This, I believe, is an epistemological project to push our vocabulary beyond pious self-cultivation allowing us to pay attention to times where ethical subjects act not-immediately-ethical (yet might not terribly unethical either).

There is also an ontological aspect in this debate that is yet to be addressed thoroughly. Areas related to enjoyment and pleasure do not need to fall out of the boundaries of religion for many forms of Islam as it does in Catholicism. This was recently addressed by Ulu Sametoglu where she discusses the concept "halal circle", helal dairesi in Turkish, that refers to a range of pleasures a Muslim can enjoy without committing any $\sin (2013 ; 2015)$. Pleasure and enjoyment, in this understanding, do not pose an immediate threat to religious rigour but are considered as blessings and thus vehicles for believers to be thankful to God.

In this context, the fourth wave of feminist scholarship began to emerge in a way that, inevitably, prioritised an ethnographic interest in seemingly non-religious aspects of the lives of gendered Muslims to reflect the multifaceted and fluid nature of the subjectivation process and how it reflects imaginative aspects of self-formation, such as aspirations. Capturing the fluidity was, in some work, best achieved by focusing on ordinariness, daily pleasures, and everyday life. For this aim, in her ethnography on agency and shifting ideas about gender in Gaza, Aitemad Muhanna (2016) focuses on everyday politics under siege, insecurity, and conflict. Her work brings forward the complex processes of gendered agency and self-making that is cultivated through aspirations.

The fourth wave ethnographically grounded the theoretical debate that points to the fluidity, multiplicity, and temporality of subjecthood (Luhrmann 2006; Moore 2007; Ortner 2005). One good example to this, is Amélie Le Renard's sociological analysis of Saudi women, in which she traces the ways in which Saudi women interact with multiple norms and thus develop new subjectivations and form multiple femininities (Le Renard 2011, 2014). Le Renard's work is the second significant attempt to reflect 
the true fabric of women's lives in Saudi society, after Soraya Altorki's ethnographic fieldwork on elite Saudi women, a good example to second wave. Both of these works reflect the main characteristics of the feminist scholarship of their time. Altorki's work was the first extensive work to focus exclusively on elite women in Saudi Arabia. She mapped out the social and everyday life of her informants in a detailed manner, reflecting the vibrant and diverse foci of the second wave. Le Renard, on the other hand, combines new subjectivity theories and queer epistemology to flesh out the diverse norms operating on women and the multiplicity of subjectivations built on them. Le Renard's work expands our understanding of Saudi women beyond the limits of nation and religion as the sole indicators of subjectivity, identity, and its politics.

\section{Muslim Women's everyday life: Piety as an imperative obstacle}

In order to highlight the aspects of religion as ethical imagination in everyday lives as an anthropologist working on a Muslim community, I believe it is imperative to first "deterritorialise" the binaries that dominate studies on desire in the Middle East and blur our sight for two reasons. First, scholars working on Muslim societies are often expected to link each one of their arguments to Islam, or to discuss how Muslim habits contrasts with Western ones, or to describe their work through religious terms, or to "say more" about stereotypical concepts issues such as veiling. Although this tendency can lead to amusing moments such as the time when a Q\&A after a presentation on female gaze and intersubjectivity amongst undressing women in changing rooms in Istanbul started with a question for the presenter to "discuss and define and describe the veil"; it is still, almost exclusively, irksome.

The intellectual perspective that prioritises religion also limits our concept of selfformation and overshadows the fact that selves are contradictory, multiple, and fragmented. One efficient way to move beyond these limits, categories, classifications, binaries, and purifications, is to embrace fluidities, temporalities, shifts, and instabilities as they exist in the lives of individuals.

I find Schielke's significantly provocative statement quite timely: "there is too much Islam in the anthropology of Islam" (2010: 2). It is timely since it appeared after the third wave, in which studies of piety were taking over the post-9/11 scholarship on Muslims and proposed to understand them as -primarily- ethical subjects. He raised the possibility of studying "people's lives in a way that credits the importance of religious and other traditions, ideologies and expectations without losing sight of the complexities of life" (ibid: 3).

This query suggested a departure from Asadian approach - and was immediately critiqued by Asadians. Amira Mittermaier, for instance, cautioned against Schielke's call suggesting it bears "the risk of reinscribing Islam as a bounded entity while portraying everyday life as overly compartmentalized" (Mittermaier 2014:280). A similar statement was also made shortly after Mittermaier, by Fadil and Fernando (2015)- yet, I am not convinced that Schielke's contention runs such a risk.

If we read his point as a response to epistemologies of this particular scholarship, we can see that Schielke's provocation is valuable in a scholarly environment where a) any work on subjects who happen to be Muslims is immediately associated with Islam (anthropology of, sociology of, etc.) and b) young scholars and $\mathrm{PhD}$ 
students think they need to look at religious or pious forms of self-making if they are working on individuals who happen to be Muslim.

I do understand and celebrate the work on religious women's interpretations of their everyday lives, as some of my religious informants had very clear ideas on how exercise, for instance, might even bring them sevap (thawab - reward in afterlife). However, as I elaborate further in the following pages, that it is necessary to expand the discussion beyond the trope of self-cultivation, not only to capture the multiplicity of subjecthood, but also to recognise the dynamic nature of women's subjectivity.

I observe a pattern in work on Muslim societies that the platitudinous binary of sacred vs. profane famously worked by Émile Durkheim (1915), then echoed in other binaries in sociology and anthropology of Islam: traditional vs. modern, Islamic vs. secular, Islam vs. the West. This binary thinking (of secular vs religious) is so foundational (and tempting) in anthropology and sociology (of religion and religious subjects) that even attempts to complicate thinking can easily be reduced to a reformed version of this binary.

Studies of everyday life, desire, aspiration, and enjoyment of Muslims, of course, risk being blocked by such inherited perspectives. In light of this risk, Fadil and Fernando (2015), have drawn attention to how the opposition between piety and the everyday is in fact an opposition "between textual norm and individual practice" and therefore "untenable" (63). I find this critique especially important to understand the everyday ethical calculations and evaluations of religious individuals' mundane acts. For instance, nail polish was subject of concern for a religious woman I talked to in Istanbul who prays (namaz) five times a day and takes abdest (ritualistic cleaning with water) for each namaz. Nail polish obviously poses a threat to a proper abdest (water needs to reach every bit of washed areas) and without a proper abdest there would be no proper namaz. However, not every Muslim individual centralises religion in their everyday life in the same manner and intensity, which is a question of subjectivity as I discuss below.

\section{The new feminist task: Exploring Muslim Women's creative agency}

For my purposes here, what is even more significant in the debate on piety vs. the everyday is whether it allows any conceptual space for us to recognise women's agency, or any other agentive moments. Obviously, Mahmoodian analysis presents efforts of ethical self-making as agentive processes that defy liberal assumptions, as she clearly argues. But then, there are often not one, but multiple (patriarchal) systems that operate on women, so it is only reasonable to assume that women's ability to manoeuvre through multiple patriarchal systems (neoliberalism, nationalism, religion) should be non-linear, and multiple. Considering how Mahmood critiques the failure to recognise agency beyond the realms of resistance, I believe another approach is possible.

A strong and illuminating contribution to the issue on agency (and gender) comes from the post-structuralist feminist political theorist Lois McNay. According to McNay (2000), Foucaultian theory of subjectivity fails to recognise generative human agency because, from its perspective, "the process of subjectification is understood as a dialectic of freedom and constraint" (2000:2). Thus, the conceptualisation of selfhood remains passive with respect to discourse and discursive practices and agency are left 
limited, partial, and negative (2003). McNay, therefore, calls upon feminists to develop a generative (2003:140-141) framework in order to reveal the creative aspects of agency $(2000,2008)$. This proposal was not new to feminist scholarship. Mahmood (2005), McNay (2000) and Moore (1994, 2007) share parallel views on desire, subjectivity, and agency in their feminist formulation, which I will come back.

McNay's approach has several crucial contributions that would be significant to Middle Eastern feminist scholarship. Firstly, she joins the critique to Western feminism (and the existing post-structuralist stream in it) and develops her theory distancing herself from the essentialist and liberalist tendencies in Western feminist scholarship. Secondly, she proposes to diverge from an analysis that defines subjects only through the workings of power. In this vein, her approach fits well into the fourth wave's concerns as it seeks to go beyond limited and one-dimensional subjectivities, including pious forms of subjecthood. By over-emphasising religion in the lives of Muslim women, the piety turn has tended to minimise women's other forms of agency in navigating multiple social structures, expectations, and pressures in their daily lives - which is curious considering how part of the second wave dealt directly with women's "bargain" with such multiple systems (Kandiyoti 1988). Thirdly, she calls for a more dynamic, multifaceted, fluid yet unified subjectivity and thus, is able to propose a more grounded formulation of agency. This third element can be seen in several other scholars in the last decade, such as in Ewing, Ortner, Luhrmann, and Moore. And the connection between a proper formulation of selfhood and agency is followed.

Almost a decade earlier than McNay, Henrietta Moore suggested that "any approach to the analysis of agency must include a consideration of the role of fantasy and desire, both with regard to questions of compliance and resistance and in connection with the construction of a sense of self" (Moore 1994: 5). It is not possible to understand the workings of agency or the relationship between the social and the individual without understanding fantasy and desire (as well as fear) (Moore 1994), which are their creative aspects. Moore's call is echoed in psychoanalytical approaches. Inspired by the Lacanian analysis of enjoyment, Glynos and Stavrakakis (2008) suggest that any formulation of subjectivity that ignores the realms of enjoyment and fantasy will lead to an insubstantial account of agency. Moore (2007) draws our attention to the connection between fantasy, desire, and enjoyment from a psychoanalytical perspective. By employing the approach of Žižek and Lacan, she draws our attention to the unconscious as a dynamic area that connects the social and the subject. These areas easily escape a symbolic or linguistic analysis since they are objet $a$, as Lacan terms them. This perspective, as Moore explains clearly, "provides the basis for the assertion that the social and the psychic are not isomorphic, that the self can never be wholly determined by culture" (Moore 2007: 57). That is to say, there are always some "leftovers" that escape cultural determination and resist "symbolisation", which provides an area for enjoyment that connects "the subject's fantasized relations to [these] leftovers" (ibid).

Those leftovers, are about the way in which individuals express and make themselves against, in relation to, and side by side with these rules while pursuing their desiring selves (Rofel 2007). This, is a salient aspect of human agency. Desire, as a human capacity, provides one of the venues through which individuals seek possibilities which makes it essential in understanding agency. 
Suad Joseph (2005) offers one recent attempt to connect women's desire to their agency while challenging the existing theories on desire. In her article, Joseph provided a post-colonial feminist critique of the very formulation of the concept of desire. She suggested that liberal understandings of desire have long ignored non-Western forms of desire because of their liberal, and hence narrow, formulation. Instead, she suggested, ethnographic interest should be directed to what she called "relational pedagogies - how local constructs of desire, configured within notions of relational selfhood, [are] ... learned, taught, and practiced in their own contexts" (Joseph 2005: 80). Joseph was referring to the makings, meanings, and expressions of desire as they are formed through historical, religious, familial, and social processes. In her work on the Arab community of Camp Trad in Beirut, Joseph challenges such approaches to desire and insists that anthropologists recognise its "local constructs". In this ethnographic context, desires are "configured within notions of relational selfhood, [and are] ... learned, taught, and practiced in the context of intimate patriarchal familial and communal relationships" (Joseph 2005: 80).

\section{Conclusion}

On the one hand the preoccupation with agency, (ie. an exclusive focus on it) in studies on the women in the Middle East runs the risk of evoking the colonial narrative and feminist and queer scholars need to be aware of that. However, on the other hand, those colonial narratives are in fact embedded into the very epistemology of area studies which is why they keep haunting academic scholastic view at many levels. Due to the politics of epistemology as a feminist issue (Alcoff 1993), it is not only hard, but also politically impossible for the feminist scholarship to avoid reflecting on agency, at different levels and different ways, in different times. As reviewed in this paper, the ways in which women's agency is approached and addressed have experienced shifts and turns, reflecting the theoretical and conceptual debates of the time.

Having said that, it also became apparent, as I discussed throughout this review, that agency is no longer seen as a human quality embedded into subjects, rather, is formed through a process of interaction between the individuals and the larger social mechanisms operating on them. Patriarchal ideologies are one of those mechanisms, often taking multiple shapes and forms. Ethnographic focus should constantly be recalibrated to capture the fluidity of agency, that might not always resist to, but finds other ways to escape from, patriarchal ideologies. In this vein, feminist scholarship of the Middle East would continue approaching to Muslim women's agency -as it has been doing for decades- as an epistemological question, only without ignoring the multiplicity of women's subjectification, which inevitably embraces realms of aspiration, desire, and enjoyment.

Acknowledgments I would like to thank Henrietta Moore, Jeremy Walton, and Giulia Liberatore for their comments to earlier versions of this paper. This paper was completed during a visiting research fellowship in Contemporary Turkish Studies of the European Institute at London School of Economics and for this, I would like to thank Esra Özyürek's guidance. 
Open Access This article is distributed under the terms of the Creative Commons Attribution 4.0 International License (http://creativecommons.org/licenses/by/4.0/), which permits unrestricted use, distribution, and reproduction in any medium, provided you give appropriate credit to the original author(s) and the source, provide a link to the Creative Commons license, and indicate if changes were made.

\section{References}

Abu Odeh, L. (1993). Post-colonial feminism and the veil: Thinking the difference. Feminist Review, 43, 2637.

Abu Zahra, N. M. (1970). On the modesty of women in Arab Muslim villages: A reply. American Anthropologist, 72(5), 1079-1092.

Abu-Lughod, L. (1986). Veiled sentiments : Honor and poetry in a Bedouin society. Berkeley: University of California Press.

Afshar, H. (Ed.). (1993). Women in the Middle East: Perceptions, realities and struggles for liberation. London: Palgrave Macmillan.

Ahmed, L. (1982). Western ethnocentrism and perceptions of the harem. Feminist Studies, 8(3), 521-534.

Al-Ali, N. (2000). Secularism, gender and the state in the Middle East: The Egyptian women's movement (Vol. 14). Cambridge: Cambridge University Press.

Alloula, M. (1986). The colonial harem. Minneapolis: University of Minnesota Press.

Al-Qasimi, N. (2010). Immodest modesty: Accommodating dissent and the'AbAya-as-fashion in the Arab gulf states. Journal of Middle East Women's Studies, 6(1), 46-74.

Altinay, R. E. (2013). Șule Yüksel Șenler: An Early Style Icon of Urban Islamic Fashion in Turkey. In E. Tarlo \& A. Moors (Eds.), Islamic Fashion and Anti-Fashion: New Perspectives from Europe and North America, (pp. 107-122). London: Bloomsbury Academic.

Altorki, S. (1986). Women in Saudi Arabia : Ideology and behavior among the elite. New York: Columbia University Press.

Antoun, R. T. (1968). On the modesty of women in Arab Muslim villages: A study in the accommodation of traditions. American Anthropologist, 70(4), 671-697.

Arat, Y. (1989). The patriarchal paradox: Women politicians in Turkey. Madison: Fairleigh Dickinson Univ Press. Asad, T. (Ed.). (1973). Anthropology and the colonial encounter. London: Ithaca Press and Humanities Press.

Asad, T. (2003). Formations of the secular: Christianity, Islam, modernity. Palo Alto: Stanford University Press.

Asad, T. (2007). On suicide bombing. New York: Columbia University Press.

Aswad, B. C. (1967). Key and peripheral roles of noblewomen in a middle Eastern Plains village. Anthropological Quarterly, 40, 139-152.

Aswad, B. C. (1974). Visiting patterns among women of the elite in a small Turkish City. Anthropological Quarterly, 47, 9-27.

Aswad, B. C. (1978). Women, class, and power: Examples from the Hatay, Turkey. In L. Beck \& N. Keddie (Eds.), Women in the Muslim World. Cambridge: Harvard University press.

el-Aswad, E.-S. (2012). Muslim worldviews and everyday lives. Lanham: Rowman Altamira.

Badran, M. (1996). Feminists, Islam, and nation: Gender and the making of modern Egypt. Princeton: Princeton University Press.

Balasescu, A. (2007). Haute couture in Tehran: Two faces of an emerging fashion scene. Fashion Theory, $11(2-3), 299-317$.

Bangstad, S. (2011). Saba Mahmood and anthropological feminism after virtue. Theory, Culture \& Society, $28(3), 28-54$.

Barlas, A. (2002). "Believing Women" in Islam: Unreading Patriarchal Interpretations of the Qur'ān. Austin: University of Texas Press.

Bautista, J. (2008). The meta-theory of piety: Reflections on the work of Saba Mahmood. Contemporary Islam, 2(1), 75-83.

Bayat, A. (2002). Piety, privilege and Egyptian youth. Isim Newsletter, 10, 23.

Bayat, A. (2013). Life as politics: How ordinary people change the Middle East. Palo Alto: Stanford University Press.

Bell, V. (2008). Culture and performance: The challenge of ethics, politics and feminist theory. BERG: Oxford - New York.

Benedict, P. (1974). The Kabul Gunu: Structured visiting in an Anatolian provincial town. Anthropological Quarterly, 47, 28-47. 
Benn, T., \& Pfister, G. (2010). Muslim women and sport. London: Routledge.

Boddy, J. (1989). Wombs and alien spirits: Women, men and the Zar cult in northern Sudan. Madison: University of Wisconsin Press.

Boroumand, L., \& Boroumand, R. (2002). Terror, Islam, and democracy. Journal of Democracy, 13(2), 5-20.

Bracke, S. (2008). Conjugating the modern/religious, conceptualizing female religious agency: Contours of a 'post-secular' conjuncture. Theory, Culture \& Society, 25(6), 51-67.

Braidotti, R. (2008). In spite of the times: The Postsecular turn in feminism. Theory, Culture \& Society, 25(6), 1-24. https://doi.org/10.1177/0263276408095542.

Braidotti, R. (2009). Postsecular feminist ethics. Intimate Citizenships: Gender, Sexualities, Politics, $18,40$.

Bullock, K. (2002). Rethinking Muslim women and the veil: Challenging Historical \& Modern Stereotypes. London: The International Institute of Islamic Thought.

Butler, J. (1990a). Gender trouble and the subversion of identity. New York and London Routledge.

Butler, J. (1990b). Performative acts and gender constitution: An essay in phenomenology and feminist theory. In S.E. Case (Ed.), Performing feminisms: Feminist critical theory and theatre. Baltimore: Johns Hopkins UP.

Butler, J. (1999). Bodies that matter. In Janet Price, Margrit Shildrick (Eds) Feminist theory and the body: A reader (pp. 235-245). New York: Routledge.

Deeb, L. (2006). An enchanted modern: Gender and public piety in Shi'i Lebanon. Princeton: Princeton University Press.

Deeb, L. (2015). Thinking piety and the everyday together: A response to Fadil and Fernando. HAU: Journal of Ethnographic Theory, 5(2), 93-96.

Deeb, L., \& Harb, M. (2013). Leisurely Islam: Negotiating geography and morality in Shi'ite South Beirut. Princeton: Princeton University Press.

Deeb, L., \& Winegar, J. (2012). Anthropologies of Arab-majority societies. Annual Review of Anthropology, $41,537-558$.

Durkheim, E. (1915). Definition of religious phenomena and of religion. The Elementary Forms of the Religious Life: A Study in Religious Sociology, 36-47.

Dwyer, D. H. (1978). Ideologies of sexual inequality and strategies for change in male-female relations. American Ethnologist, 5(2), 227-240.

Early, E. A. (1993). Baladi women of Cairo: Playing with an egg and a stone. London: Lynne Rienner Publishers.

Ewing, K. P. (2008). Stolen honor: stigmatizing Muslim men in Berlin. Stanford: Stanford University Press.

Fadil, N., \& Fernando, M. (2015). Rediscovering the "everyday" Muslim: Notes on an anthropological divide. HAU: Journal of Ethnographic Theory, 5(2), 59-88.

Fallers, L. A., \& Fallers, M. C. (1976). Sex roles in Edremit. In J. G. Peristiany (Ed.), Mediterranean family structures (pp. 243-260). Cambridge: Cambridge University Press.

Farooq, S. (2010). Muslim women. In Islam and sport: 'race', culture and identity in post-colonial Britain. Coventry: University of Warwick.

Farsoun, S., \& Farsoun, K. (1974). Family structure and Society in Modern Lebanon. Anthropological Quarterly, 47, 93-111.

Fernea, E., \& Bezirgan, B. (1977). Middle eastern women speak. Austin: University of Texas Press.

Foucault, M. (1976). L'Histoire de la Sexualité. Paris: Gallimard.

Foucault, M. (1978). The history of sexuality (R. Hurley, Trans.). New York: Pantheon.

Glynos, J., \& Stavrakakis, Y. (2008). Lacan and political subjectivity: Fantasy and enjoyment in psychoanalysis and political theory. Subjectivity, 24(1), 256-274.

Gökariksel, B., \& McLarney, E. (2010). Muslim women, consumer capitalism, and the Islamic culture industry. Journal of Middle East Women's Studies, 6(3), 1-18.

Gökarısel, B., \& Secor, A. (2010). Islamic-ness in the life of a commodity: Veiling-fashion in Turkey. Transactions of the Institute of British Geographers, 35(3), 313-333.

Good, M.-J. V. (1978). A comparative perspective on women in provincial Iran and Turkey. In L. Beck \& N. Keddie (Eds.), Women in the Muslim World. Cambridge: Harvard University Press.

Granqvist, H. (1947). Birth and childhood among the Arabs: Studies in a Muhammadan Village in Palestine. Helsingfors: Helsinki.

Hansen, H. (1961). The Kurdish Woman's life. Copenhagen: Abe Books.

Harb, M., \& Deeb, L. (2013). Contesting urban modernity: Moral leisure in south Beirut. European Journal of Cultural Studies.

Harper, M. (1985). Recovering the other: Women and orient in the writings of early nineteenth century France. Critical Matrix, 1(3), 2.

Hasan, N. (2009). The making of public Islam: Piety, agency, and commodification on the landscape of the Indonesian public sphere. Contemporary Islam, 3(3), 229-250.

Hasso, F. (2010). Consuming desires: Family crisis and the state in the Middle East. Palo Alto: Stanford University Press. 
Hazbun, W. (2008). Beaches, ruins, resorts: The politics of tourism in the Arab world. Minneapolis: U of Minnesota Press.

Hefner, R. W. (2001). Public Islam and the problem of democratization. Sociology of Religion, 62(4), 491-514.

Hefner, R. W. (2011). Civil Islam: Muslims and democratization in Indonesia. Princeton: Princeton University Press.

Henkel, H. (2007). The location of Islam: Inhabiting Istanbul in a Muslim way. American Ethnologist, 34(1), 57-70.

Heryanto, A. (2011). Upgraded piety and pleasure: The new middle class and Islam in Indonesian popular culture. In A. N. Weintraub (Ed.), Islam and Popular Culture in Indonesia and Malaysia (pp. 6082). Abingdon and New York: Routledge.

Hirschkind, C. (2006). The ethical soundscape: cassette sermons and Islamic counterpublics. New York: Columbia University Press.

Huq, M. (2003). From piety to romance: Islam-oriented texts in Bangladesh. In D. F. Eickelman, J. W. Anderson (Eds.), New media in the Muslim world: The emerging public sphere (pp. 129-157). Bloomington and Indianapolis: Indiana University Press.

Hoodfar, H. (1992). The veil in their minds and on our heads: The persistence of colonial images of Muslim women. Resources for Feminist Research, 22(3/4), 5.

Hoodfar, H. (1997). Between marriage and the market: Intimate politics and survival in Cairo (Vol. 24). Berkeley: Univ of California Press.

Hoodfar, H. (2015). Women's sport as politics in Muslim contexts. London: Women Living Under Muslim Laws.

Huq, M. (2008). Reading the Qur'an in Bangladesh: The politics of 'belief'among Islamist women. Modern Asian Studies, 42(2-3), 457-488.

Huq, S., \& Rashid, S. F. (2008). Refashioning Islam: Elite women and piety in Bangladesh. Contemporary Islam, 2(1), 7-22.

Jones, C. (2007). Fashion and faith in urban Indonesia. Fashion Theory, 11(2-3), 211-231.

Jones, C. (2010). Materializing piety: Gendered anxieties about faithful consumption in contemporary urban Indonesia. American Ethnologist, 37(4), 617-637.

Joseph, S. (2005). Learning desire: Relational pedagogies and the desiring female subject in Lebanon. Journal of Middle East Women's Studies, 1(1), 79-109.

Kabbani, R. (1986). Europe's myths of orient. Bloomingtin: Indiana University Press.

Kandiyoti, D. (1987). Emancipated but unliberated? Reflections on the Turkish case. Feminist Studies, 13(2), 317-338.

Kandiyoti, D. (1988). Bargaining with patriarchy. Gender and Society, 2(3), 274-290.

Kandiyoti, D. (1996). Contemporary feminist scholarship and Middle East studies. In D. Kandiyoti (Ed.), Gendering the Middle East: emerging perspectives (pp. 1-27). London: IB Tauris.

Kandiyoti, D. (1991). Women, Islam, and the state. Philadelphia: Temple University Press.

Kay, T. (2006). Daughters of Islam family influences on Muslim young Women's participation in sport. International Review for the Sociology of Sport, 41(3-4), 357-373.

Keane, W. (2003). Self-interpretation, agency, and the objects of anthropology: Reflections on a genealogy. Society for Comparative Study of Society and History, 45, 222-248.

Keddie, N. R. (1979). Problems in the study of middle eastern women. International Journal of Middle East Studies, 10(2), 255-240.

Keddie, N. R., \& Beck, L. (1978). Women in the Muslim world. Cambridge: Harvard University Press.

Khalili, L. (2015). The politics of pleasure: Promenading on the corniche and beachgoing ( $\mathrm{p}$. 0263775815623538). Environment and Planning D: Society and Space.

Kilıçbay, B., \& Binark, M. (2002). Consumer culture, Islam and the politics of lifestyle: Fashion for veiling in contemporary Turkey. European Journal of Communication, 17(4), 495-511.

Leacock, E. (1978). Women's status in egalitarian society: implications for social evolution. Current Anthropology, 19(2), 247-275.

Le Renard, A. (2011). Femmes et espaces publics en Arabie Saoudite. Paris: Dalloz.

Le Renard, A. (2014). A society of young women: Opportunities of place, power, and reform in Saudi Arabia. Palo Alto: Stanford University Press.

Lewis, B. (2004). The crisis of Islam: Holy war and unholy terror. New York: Random House Digital, Inc..

Lewis, R. (2013). Modest fashion: Styling bodies, mediating faith. New York: IB Tauris.

Luhrmann, T. M. (2006). Subjectivity. Anthropological Theory, 6, 345-359.

Maher, V. (1974). Women and property in Morocco: Their changing relation to the process of social stratification in the middle atlas (Vol. 10). Cambridge: CUP Archive.

Mahmood, S. (2005). Politics of piety: The Islamic revival and the feminist subject. New Jersey: Princeton University Press.

Makhlouf, C. (1979). Changing veils: Women and modernisation in North Yemen. London: Croom Helm London. 
Mamdani, M. (2002). Good Muslim, bad Muslim: A political perspective on culture and terrorism. American Anthropologist, 104(3), 766-775.

McNay, L. (2000). Gender and agency: Reconfiguring the subject in feminist and social theory. Cambridge: Polity Press.

Menin, L. (2011). Bodies, boundaries and desires: Multiple subject-positions and micro-politics of modernity among young Muslim women in Milan. Journal of Modern Italian Studies, 16(4), 504-515.

Menoret, P. (2014). Joyriding in Riyadh: Oil, urbanism, and road revolt. Cambridge: Cambridge University Press.

Mernissi, F. (1987). Beyond the veil: Male-female dynamics in modern Muslim society (Vol. 423). Bloomington: Indiana University Press.

Mir-Hosseini, Z. (1993). Marriage on trial, a study of Islamic family law in Iran and Morocco. London: I.B. Tauris.

Mittermaier, A. (2014). Trading with god: Islam, calculation, excess. In J. Boddy \& M. Lambek (Eds.), A Companion to the Anthropology of Religion (pp. 274-293). West Sussex: Wiley Publications.

Moghadam, V. M. (Ed.). (1994). Gender and national identity: women and politics in Muslim societies. Helsinki: Zed Books.

Moore, H. L. (1988). Feminism and anthropology. Cambridge: Polits.

Moore, H. L. (1994). A passion for difference: Essays in anthropology and gender. Cambridge: Polity Press.

Moore, H. L. (2007). The subject of anthropology: Gender symbolism and psychoanalysis. Cambridge: Polity Press.

Moore, H. L. (2011). Still life: Hopes, desires and satisfactions. Cambridge: Polity Press.

Moors, A. (1991). Women and the orient: A note on difference. In L. N. a. P. Pels (Ed.), Constructing knowledge (pp. 114-122). London: Sage.

Moors, A. (2009). "Islamic fashion" in Europe: religious conviction, aesthetic style, and creative consumption. Encounters, 1(1), 175-201.

Muhanna, A. (2016). Agency and gender in Gaza: Masculinity, femininity and family during the second intifada. London: Routledge.

Ortner, S. B. (2005). Subjectivity and cultural critique. Anthropological Theory, 5, 31-46.

Ortner, S. B. (2016). Dark anthropology and its others: Theory since the eighties. HAU: Journal of Ethnographic Theory, 6(1), 47-73.

Osella, C., \& Osella, F. (2007). Muslim style in South India. Fashion Theory: The Journal of Dress, Body \& Culture, 11(2-3), 2-3.

Ozyegin, G. (2015). New desires, new selves: Sex, love, and piety among Turkish youth. New York: NYU Press.

Palmer, M., \& Palmer, P. (2004). At the heart of terror: Islam, jihadists, and America's war on terrorism. Lanham: Rowman \& Littlefield.

Peek, L. (2005). Becoming Muslim: The development of a religious identity. Sociology of Religion, 66(3), 215-242.

Reed, H. (1957). The religious life of modern Turkish Muslims. In R. N. Frye (Ed.), Islam and the West. The Hague: Mouton and Co.

Reiter, R. R. (1975). Introduction. In R. R. Reiter (Ed.), Toward an Anthropology of Women (pp. 11-19). New York: Monthly Review Press.

Rofel, L. (2007). Desiring China: Experiments in neoliberalism, sexuality, and public culture. London: Duke University Press.

Rogers, S. C. (1975). Female forms of power and the myth of male dominance: a model of female/male interaction in peasant society. American Ethnologist, 2(4), 727-756.

Rozario, S. (2011). Islamic piety against the family: From 'traditional'to 'pure'Islam. Contemporary Islam, 5(3), 285-308.

Said, E. W. (1978). Orientalism: Western conceptions of the orient. New York: Pantheon.

Sandikci, O., \& Ger, G. (2007). Constructing and representing the Islamic consumer in Turkey. Fashion Theory: The Journal of Dress, Body \& Culture, 11(2-3), 2-3.

Schielke, S. (2010). Second thoughts about the anthropology of Islam, or how to make sense of grand schemes in everyday life. ZMO Working Papers, 2, Berlin.

Schielke, J. S., \& Debevec, L. (2012). Ordinary lives and grand schemes: An anthropology of everyday religion (Vol. 18). New York: Berghahn Books.

Sehlikoglu, S. (2013). Boundaries of a veiled female body: Islamic reflections on Women's sporting bodies in relation to sexuality, modesty and privacy. Anthropology News, 53(6: In focus: Olympics).

Sehlikoglu, S. (2014a). Imagining the self as sporting body. Cultural Anthropology Fieldsights-Field Notes (Online).

Sehlikoglu, S. (2014b). Mahrem Alanda Fit Olmak: Kadınlara Mahsus Spor Salonları. Sinır Bilgisi: Siyasal İktidar, Toplumsal Mekân ve Kadına Yönelik Şiddet(Çelebi, Elif; Havlioğlu, Didem; Ebru, Kayaalp), 55-75.

Sehlikoglu, S. (2016). Exercising in comfort: Islamicate culture of Mahremiyet in everyday Istanbul. Journal of Middle East Women's Studies, 12(2), 143-165. 
Mojab, S. (2001). The politics of theorizing "Islamic feminism" - Implications for international feminist movements. In H. Kapoor (Ed.), Women Living Under Muslim Laws, Dossier (pp. 23-24, 64-80). London: WLUML.

Shively, K. (2005). Religious bodies in secular states: The veil in Turkey and France. In Paper presented at the Summer Institute of teaching and research on women: Turkey at the crossroads: Women. Women's: Studies and State.

Soares, B. F. (2004). Islam and public piety in Mali. Leiden: Brill.

Soares, B., \& Osella, F. (2009). Islam, politics, anthropology. Journal of the Royal Anthropological Institute, $15(\mathrm{~s} 1), \mathrm{S} 1-\mathrm{S} 23$.

Tapper, N. (1978). The Women's subsociety among the Shahsevan nomads of Iran. In L. Beck \& N. Keddie (Eds.), Women in the Muslim World. Cambridge: Harvard University Press.

Tarlo, E. (2010). Visibly muslim: Fashion, politics, faith. Louvigny: Berg.

Tarlo, E., \& Moors, A. (2007). Fashion theory: Introduction. The Journal of Dress, Body \& Culture, 11(2), $133-142$.

Tarlo, E., \& Moors, A. (2013). Islamic fashion and anti-fashion: New perspectives from Europe and North America. London: A\&C Black.

Tong, J. K.-C., \& Turner, B. S. (2008). Women, piety and practice: A study of women and religious practice in Malaysia. Contemporary Islam, 2(1), 41-59.

Ulu Sametoglu, S. (2013). Halal circle: Leisure, humour, and aesthetic spaces created by young Muslim women of Gulen movement $i$ France and Germany. Leuven: Paper presented at the Everyday Life Practices of Muslims in Europe.

Ulu Sametoglu, S. (2015). Halalscapes: Leisure, fun and aesthetics spaces created by young Muslim women in France and Germany. In E. Togsl (Ed.), Everyday life practices of Muslims in Europe (pp. 143-161). Leuven: Leuven University Press.

Vreede-de Stuers, C. (1968). Parda: A study of Muslim Women's life in northern India. New York: Greenwood Press.

Watson, H. (1992). Women in the City of the dead. Lawrenceville: Africa World Press.

Weintraub, A. N. (2011). Islam and popular culture in Indonesia and Malaysia. New York: Routledge, Taylor \& Francis.

Widodo, A. (2008). Writing for god: Piety and consumption in popular Islam. Inside Indonesia, 93. http://insideindonesia.org/content/view/1121/47/. Accessed 13 Sept 2014.

Winegar, J. (2006). Creative reckonings: The politics of art and culture in contemporary Egypt. Palo Alto: Stanford University Press.

Winegar, J. (2008). The humanity game: Art, Islam, and the war on terror. Anthropological Quarterly, 81(3), 651-681.

Yaqin, A. (2007). Islamic Barbie: The politics of gender and performativity. Fashion Theory: The Journal of Dress, Body \& Culture, 11(2-3), 2-3.

Yeğenoğlu, M. (1998). Colonial fantasies: Towards a feminist reading of orientalism. Cambridge: Cambridge University Press.

Yuval-Davis, N., Anthias, F., \& Campling, J. (1989). Woman, nation, state. Basingstoke: Macmillan.

Zuhur, S. (1992). Revealing reveiling: Islamist gender ideology in contemporary Egypt. Albany: SUNY Press. 